\title{
A DEFECT IN THE METABOLISM OF TYROSINE AND PHENYL- ALANINE IN PREMATURE INFANTS. III. DEMON- STRATION OF THE IRREVERSIBLE CONVERSION OF PHENYLALANINE TO TYROSINE IN THE HUMAN ORGANISM
}

\author{
By S. Z. LEVINE, MARGARET DANN, AND ELEANOR MARPLES \\ (From the New York Hospital and the Department of Pediatrics, Cornell University Medical \\ College, New York City)
}

(Received for publication January 11, 1943)

In preceding papers $(1,2)$, it was shown that premature infants fed vitamin C-free cow's milk mixtures, high in protein ( 5 grams or more per kgm. per day), exhibit a spontaneous defect in their metabolism of tyrosine and phenylalanine, manifested by the urinary excretion of 1-p-hydroxyphenyllactic and p-hydroxyphenylpyruvic acids. The defect was accentuated by feeding these subjects either amino acid in pure form. Full-term infants fed similar diets did not show the defect spontaneously but it could be induced in them by the ingestion of a single dose (1.0 gram per $\mathrm{kgm}$.) of either amino acid. It was further shown that the administration of 1ascorbic acid in adequate dosage abolished the spontaneous and artificially induced defect in both premature and full-term infants.

The presence of this metabolic aberration prompted a more detailed study of the response of infants to repeated oral doses of tyrosine and phenylalanine, with and without dietary vitamin C. In this study, the assays for urinary aromatic organic acids were supplemented by urinary assays for the amino acids themselves. These modified procedures threw further light on the pathways of intermediary aromatic amino acid metabolism and provided evidence of the irreversible conversion of phenylalanine to tyrosine by the living, normal human organism.

\section{REVIEW OF THE LITERATURE}

Available evidence establishes that the animal organism is able to form tyrosine and its derivatives from phenylalanine. The evidence is derived from three main lines of experimental approach: perfusion experiments, animal studies, and human observations.

\section{Perfusion experiments}

Following perfusion of dogs' livers with dog's blood containing d,1-phenylalanine, Embden and his coworkers (3) were able to isolate 1-tyrosine from the blood. They concluded that the conversion occurred by oxidation of the benzene ring, either directly or through the intermediation of p-hydroxyphenylpyruvic acid by simultaneous oxidative deamination of the side chain, the keto acid having previously been shown to form 1tyrosine in liver perfusion experiments (4).

\section{Animal studies}

These studies demonstrate: $A$. the essential nature of phenylalanine as a dietary component for the growing rat and the non-essential nature of tyrosine, the evidence indicating that the tyrosine of body protein on tyrosine-free diets is synthesized in vivo from dietary phenylalanine $(5) ; B$. the presence of tyrosine derivatives ( $p$-hydroxyphenylpyruvic acid, p-hydroxyphenyllactic acid, homogentisic acid, and even tyrosine itself) in the urine of white rats (6), scorbutic guinea pigs (7), and rabbits (8), following ingestion of phenylalanine; and $C$. the deposition of deutero-tyrosine in the body of rats from ingested d,1-deuterophenylalanine (9) and deutero-phenyllactic acid (10).

\section{Human observations}

All previously reported human observations except those on infants $(1,2)$ were made on patients suffering from inborn errors of aromatic amino acid metabolism. Neubauer and Falta (11) and later workers (12) found that alkaptonuric patients who spontaneously excrete homogentisic acid augment their urinary excretion of 
this acid when fed phenylalanine or its derivatives, phenylpyruvic and phenyllactic acids. Medes (13), in a single case of tyrosinosis, characterized by the spontaneous excretion of p-hydroxyphenylpyruvic acid, found that the ingestion of phenylalanine led to a marked increase in the urinary output of this keto derivative of tyrosine, and to the appearance in the urine of the hydroxy derivative of tyrosine, $\mathrm{p}$-hydroxyphenyllactic acid, and, in lesser amounts, of tyrosine itself. In contrast to the above observations, it is interesting to note that in the metabolic aberration, phenylpyruvic oligophrenia, characterized by the spontaneous excretion of phenylpyruvic acid, the administration of phenylalanine is entirely without effect on the urinary output of tyrosine or its keto and hydroxy derivatives (14).

Except for the single case recorded by Medes (13), none of the published studies present direct evidence of an in vivo conversion of phenylalanine to tyrosine in the human organism and the question may properly be asked whether the demonstrated conversion in this single instance represents the customary normal pathway of human intermediary metabolism. The metabolic defect, previously described in infants, provided a means of studying this conversion and its irreversibility in the normal human organism.

\section{METHODS}

\section{Subjects}

Eight healthy male premature infants, ranging in age from 8 to 22 days and weighing from 1.87 to $2.34 \mathrm{kgm}$. at the start of observations, were studied on diets of vitamin C-free cow's milk throughout periods of from 7 to 44 days, for a total of 129 days. Two male fullterm infants, aged 17 and 20 days and weighing 3.88 and $3.54 \mathrm{kgm}$. at the start of observations, were studied on similar diets in periods of 13 and 12 days, respectively. All infants resided in a constant temperature and humidity room and were under the supervision of 4 specially trained nurses whose duties consisted of the preparation of diets, the collection of urine, and the general care of the infants. Only one or occasionally 2 infants were studied at one time.

All of the infants took their feedings well and gained weight. During test periods of amino acid administration, transient abdominal distention was frequently observed, but regurgitation or vomiting was not frequent except in the case of A. V., who vomited small parts of many feedings. Increased frequency of defecation, and curds in the stools, were observed in 2 infants (R. Fo. and G. H.) during test periods.
Diets

A detailed description of the basal diets was given in the previous paper (2.b). Briefly, they consisted of dilutions of powdered cow's milk with cane sugar and provided approximately $150 \mathrm{cc}$. of fluid, 120 to 130 calories, and 5 to 7 grams of protein per $\mathrm{kgm}$. per 24 hours. Chemical analysis, using a modification of Bessey's method (15) revealed the absence of vitamin $C$ in the milk used. ${ }^{1}$ Twenty drops of a vitamin A and D concentrate (percomorph oil) were also given daily.

\section{Supplements}

Following adequate fore-periods of constant diet, all of the infants were given either 1-tyrosine or d, 1-phenylalanine, in amounts ranging from 0.25 to 2.00 grams per $\mathrm{kgm}$. per 24 hours, for from 1 to 5 successive days. The amino acid was mixed with small amounts of sterile water and incorporated in repeated small portions of formula at one or 2 feedings, until it was quantitatively ingested.

Of the 10 infants, 3 received no ascorbic acid during the study. One infant (R. K.) was given this vitamin for some time prior to as well as during amino acid ingestion. In the 6 remaining subjects, a series of observations was made with amino acid administration while on a vitamin C-free diet, and repeated with concurrent ingestion of varying dosage of 1-ascorbic acid.

\section{Urine}

The method for collecting urine separately from feces in infants was described in previous papers (16.a, b). Quantitative collections of urine were made throughout all observations and analyzed at the end of each 24 - or occasionally 12-hour period. The 3 compounds giving the Millon reaction, p-hydroxyphenylpyruvic acid, phydroxyphenyllactic acid, and tyrosine, were determined in the untreated urine by the Folin-Ciocalteu method (17). The urine was also analyzed separately for p-hydroxyphenylpyruvic acid by reduction of phosphomolybdic acid in acid solution, as described by Medes (13). Tyrosine, the only one of these 3 compounds insoluble in ether, was determined in the ether-extracted urine (17) after separation by continuous extraction for 24 hours. The difference between the total Millon-reacting group expressed as tyrosine, and the sum of the keto acid and tyrosine afforded a quantitative estimate of p-hydroxyphenyllactic acid (2.a). In urine containing large amounts of ascorbic acid, this compound, by its reducing action on phosphomolybdic acid, yielded falsely high values for p-hydroxyphenylpyruvic acid and correspondingly falsely low values for p-hydroxyphenyllactic acid. For this reason, only the in toto values for the 2 ethersoluble derivatives of tyrosine are given in Table II and Figure 1 for all urinary specimens in which ascorbic acid was present in interfering amounts. Phenylalanine

1 We are indebted to Captain Walter Golden for these analyses. 
was determined in the ether-extracted urine by the Kapeller-Adler method (18), interfering substances (aromatic organic acids) having been removed by preliminary extraction with ether. Only in observations on 2 infants (W. B. and R. S.) was tyrosine removed by oxidation with potassium permanganate in the cold (18) prior to the determination of phenylalanine. In the etherextracted urines of one of these infants (W. B.), phenylalanine was determined both before and after this procedure. It was found that each milligram of tyrosine actually present accounted for approximately $0.2 \mathrm{mgm}$. of apparent phenylalanine. Phenylpyruvic acid was estimated by measuring the color produced with ferric chloride, as outlined by Jervis and his coworkers (19).

\section{Feces}

Estimates of the fecal loss of amino acids (phenylalanine (19) and tyrosine (17)) following ingestion were made in two series of observations ( $R$. S. following tyrosine ingestion and L. G. after phenylalanine).

\section{RESULTS}

The detailed experimental data are presented in Tables I and II, the latter showing specifically the effect of ingestion of the aromatic amino acids, phenylalanine and tyrosine, on the urinary excretion of the former and its keto derivative, and of the latter and its keto and hydroxy derivatives.

\section{Controls}

For each subject, a control period of constant diet and urine collection preceded amino acid ingestion. Except for G. H., whose formula was changed only 2 days before the onset of observations, all of the infants had been receiving the control diet of relatively high protein content ( 5 to 7 grams per $\mathrm{kgm}$. of body weight) for at least 5 days. The control figures for urinary metabolites, given in Table II, represent the last 12 or 24 hours of constant diet before amino acid administration. In 7 of the 10 infants, including G. H., urinary analyses were also made for preceding days of the fore-periods, and the figures (not shown in the table) checked closely with the ones given in the table.

TABLE I

Age of subjects; nutritional status; experimental periods

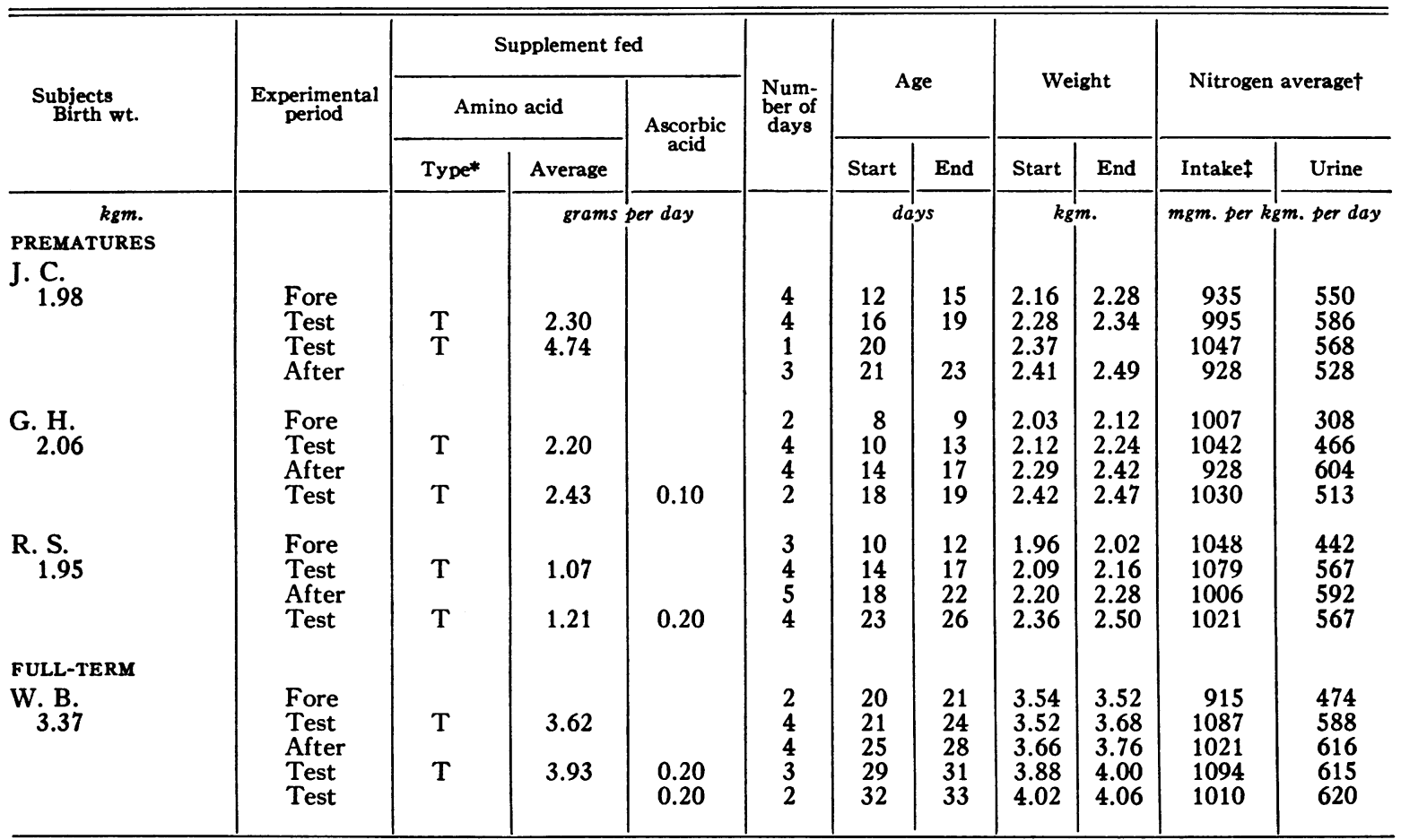

* T represents 1-tyrosine; PA, d,1-phenylalanine.

$\dagger$ Protein intake $=\mathrm{N} \times 6.25$.

$\ddagger$ Diets consisted of a powdered skimmed milk dilution (alacta) except in R. K. (evaporated cow's milk) and R. F. (powdered whole cow's milk). 
TABLE I-Continued

\begin{tabular}{|c|c|c|c|c|c|c|c|c|c|c|c|}
\hline \multirow{3}{*}{$\begin{array}{l}\text { Subjects } \\
\text { Birth wt. }\end{array}$} & \multirow{3}{*}{$\begin{array}{c}\text { Experimental } \\
\text { period }\end{array}$} & \multicolumn{3}{|c|}{ Supplement fed } & \multirow{3}{*}{$\begin{array}{l}\text { Num- } \\
\text { ber of } \\
\text { days }\end{array}$} & \multirow{2}{*}{\multicolumn{2}{|c|}{ Age }} & \multirow{2}{*}{\multicolumn{2}{|c|}{ Weight }} & \multirow{2}{*}{\multicolumn{2}{|c|}{ Nitrogen averaget }} \\
\hline & & \multicolumn{2}{|c|}{ Amino acid } & \multirow{2}{*}{$\begin{array}{c}\text { Ascorbic } \\
\text { acid }\end{array}$} & & & & & & & \\
\hline & & Type* & Average & & & Start & End & Start & End & Intakeł & Urine \\
\hline $\begin{array}{c}k g m . \\
\text { PREMATURES }\end{array}$ & & & grams & eer day & & & & $k g$ & & mgm. per & per day \\
\hline $\begin{array}{l}\text { R. K. } \\
2.08\end{array}$ & $\begin{array}{l}\text { Fore } \\
\text { Test } \\
\text { After }\end{array}$ & PA & 2.38 & $\begin{array}{l}0.025 \\
0.025 \\
0.025\end{array}$ & $\begin{array}{l}1 \\
3 \\
3\end{array}$ & $\begin{array}{l}22 \\
23 \\
26\end{array}$ & $\begin{array}{l}25 \\
28\end{array}$ & $\begin{array}{l}2.34 \\
2.36 \\
2.44\end{array}$ & $\begin{array}{l}2.40 \\
2.48\end{array}$ & $\begin{array}{l}720 \\
777 \\
683\end{array}$ & $\begin{array}{l}386 \\
377 \\
413\end{array}$ \\
\hline R. H. E. & $\begin{array}{l}\text { Fore } \\
\text { Test } \\
\text { After } \\
\text { Test } \\
\text { After } \\
\text { Test } \\
\text { After }\end{array}$ & $\begin{array}{l}\text { PA } \\
\text { PA } \\
\text { PA } \\
8\end{array}$ & $\begin{array}{l}2.30 \\
2.52 \\
5.60\end{array}$ & & $\begin{array}{l}1 \\
1 \\
1 \\
4 \\
5 \\
1 \\
1\end{array}$ & $\begin{array}{l}15 \\
21 \\
22 \\
24 \\
28 \\
33 \\
35\end{array}$ & $\begin{array}{l}27 \\
32\end{array}$ & $\begin{array}{l}2.22 \\
2.44 \\
2.43 \\
2.49 \\
2.63 \\
2.81 \\
2.93\end{array}$ & $\begin{array}{l}2.59 \\
2.80\end{array}$ & $\begin{array}{r}1017 \\
1082 \\
1006 \\
1085 \\
936 \\
1140 \\
963\end{array}$ & $\begin{array}{l}497 \\
704 \\
715 \\
836 \\
632 \\
764 \\
610\end{array}$ \\
\hline A. ${ }_{1.86}$ & $\begin{array}{l}\text { Fore } \\
\text { Test } \\
\text { After } \\
\text { Test } \\
\text { After } \\
\text { Test } \\
\text { After } \\
\text { Test } \\
\text { After } \\
\text { Test } \\
\text { After }\end{array}$ & $\begin{array}{l}\text { PA } \\
P A \\
P A \\
P A \\
P A\end{array}$ & $\begin{array}{l}2.22 \\
2.39 \\
2.74 \\
3.24 \\
3.34\end{array}$ & $\begin{array}{l}0.10 \\
0.10 \\
0.20 \\
0.10 \\
0.40 \\
0.20\end{array}$ & $\begin{array}{l}1 \\
2 \\
3 \\
5 \\
4 \\
4 \\
6 \\
4 \\
2 \\
4 \\
2\end{array}$ & $\begin{array}{l}25 \\
26 \\
28 \\
31 \\
36 \\
40 \\
44 \\
50 \\
54 \\
56 \\
60\end{array}$ & $\begin{array}{l}27 \\
30 \\
35 \\
39 \\
43 \\
49 \\
53 \\
55 \\
59 \\
61\end{array}$ & $\begin{array}{l}2.16 \\
2.20 \\
2.20 \\
2.32 \\
2.50 \\
2.70 \\
2.92 \\
3.20 \\
3.27 \\
3.30 \\
3.52\end{array}$ & $\begin{array}{l}2.20 \\
2.28 \\
2.44 \\
2.64 \\
2.82 \\
3.08 \\
3.27 \\
3.28 \\
3.42 \\
3.54\end{array}$ & $\begin{array}{r}988 \\
1055 \\
996 \\
1038 \\
983 \\
1040 \\
1000 \\
1045 \\
1020 \\
1074 \\
1013\end{array}$ & $\begin{array}{l}526 \\
557 \\
517 \\
622 \\
536 \\
545 \\
532 \\
576 \\
620 \\
696 \\
642\end{array}$ \\
\hline $\begin{array}{r}\text { R. Fo. } \\
1.66\end{array}$ & $\begin{array}{l}\text { Fore } \\
\text { Test } \\
\text { After } \\
\text { Test } \\
\text { After } \\
\text { After } \\
\text { Test } \\
\text { After } \\
\text { Test }\end{array}$ & $\begin{array}{l}\text { PA } \\
\text { PA } \\
\text { PA } \\
\text { PA }\end{array}$ & $\begin{array}{l}0.50 \\
0.58 \\
0.70 \\
0.79\end{array}$ & $\begin{array}{l}0.20 \\
0.10 \\
\\
0.20 \\
0.135 \\
0.20\end{array}$ & $\begin{array}{l}5 \\
4 \\
3 \\
4 \\
1 \\
1 \\
4 \\
5 \\
4\end{array}$ & $\begin{array}{l}17 \\
22 \\
26 \\
29 \\
33 \\
36 \\
37 \\
41 \\
46\end{array}$ & $\begin{array}{l}21 \\
25 \\
28 \\
32 \\
\\
\\
40 \\
45 \\
49\end{array}$ & \begin{tabular}{|l}
1.87 \\
1.98 \\
2.12 \\
2.24 \\
2.48 \\
2.70 \\
2.76 \\
2.92 \\
3.12
\end{tabular} & $\begin{array}{l}1.94 \\
2.08 \\
2.22 \\
2.39 \\
\\
\\
2.86 \\
3.08 \\
3.24\end{array}$ & $\begin{array}{r}1007 \\
1003 \\
987 \\
1012 \\
960 \\
935 \\
1022 \\
996 \\
1011\end{array}$ & $\begin{array}{l}488 \\
494 \\
523 \\
509 \\
468 \\
406 \\
497 \\
529 \\
586\end{array}$ \\
\hline L. G. & $\begin{array}{l}\text { Fore } \\
\text { Test } \\
\text { After } \\
\text { Test } \\
\text { After }\end{array}$ & $\begin{array}{l}\text { PA } \\
\text { PA }\end{array}$ & $\begin{array}{l}1.41 \\
1.62\end{array}$ & $0.20 \|$ & $\begin{array}{l}2 \\
4 \\
6 \\
4 \\
2\end{array}$ & $\begin{array}{l}11 \\
13 \\
17 \\
23 \\
27\end{array}$ & $\begin{array}{l}12 \\
16 \\
22 \\
26 \\
28\end{array}$ & \begin{tabular}{|l|}
2.64 \\
2.78 \\
2.92 \\
3.14 \\
3.32
\end{tabular} & $\begin{array}{l}2.72 \\
2.90 \\
3.14 \\
3.36 \\
3.40\end{array}$ & $\begin{array}{r}979 \\
1048 \\
994 \\
986 \\
911\end{array}$ & $\begin{array}{l}435 \\
433 \\
520 \\
491 \\
581\end{array}$ \\
\hline $\begin{array}{l}\text { FULL-TERM } \\
\text { R. Fr. } \\
3.50\end{array}$ & $\begin{array}{l}\text { Fore } \\
\text { Test } \\
\text { After }\end{array}$ & PA & $\begin{array}{l}4.06 \\
9.00 \\
4.04\end{array}$ & & $\begin{array}{l}1 \\
3 \\
1 \\
1 \\
6\end{array}$ & $\begin{array}{l}17 \\
18 \\
21 \\
22 \\
23\end{array}$ & $\begin{array}{l}20 \\
28\end{array}$ & $\begin{array}{l}3.88 \\
3.89 \\
4.04 \\
4.04 \\
4.00\end{array}$ & $\begin{array}{l}4.04 \\
4.16\end{array}$ & $\begin{array}{l}700 \\
841 \\
930 \\
856 \\
671\end{array}$ & $\begin{array}{l}423 \\
373 \\
532 \\
249 \\
454\end{array}$ \\
\hline
\end{tabular}

Received $2 \mathrm{cc}$. liver extract intramuscularly on 34th and 35th days.

II One day only.

High levels of excretion of the ether-soluble in fore-periods, the absence of these could be exaromatic compounds, p-hydroxyphenylpyruvic acid (the keto derivative of tyrosine) and p-hydroxyphenyllactic acid (the hydroxy derivative) were found in 5 premature infants, R. S., J. C., R. Fo., A. V., and R. H. E., and negligible amounts in the 2 full-term infants, W. B. and R. Fr. These results confirm previously reported observations $(1,2)$. In the 3 premature infants who were not excreting intermediary metabolites plained in one by the brief duration of high protein feeding (G. H.) ; in another, by the prior administration of vitamin $C(R . K$.$) . For the third$ (L. G.), no explanation is at hand.

\section{Recovery of ingested amino acid}

Figure 1 shows in graphic form the typical response of 4 subjects to amino acid ingestion, the 
increased excretion of urinary constituents above control levels being expressed as percentage of ingested amino acid recovered during test periods of from 3 to 5 days. In the case of R. S., in whom fecal loss of tyrosine was determined, the recovery is calculated as percentage of tyrosine actually absorbed. If data had been available for similar calculations in W. B., the percentage recovery would undoubtedly have been higher than that shown in Figure 1.

Columns 1 and 3 illustrate the recovery of derivatives of ingested tyrosine, and columns 5,7 , and 8 , of derivatives of ingested phenylalanine, in the absence of ascorbic acid ingestion. Columns $2,4,6,9,10$, and 11 represent the recovery of in- gested amino acid with concurrent administration of ascorbic acid. The values for columns 4 and 6 were calculated as percentage increases above original control levels because in each, the second series of amino acid observations with concurrent ingestion of vitamin $\mathrm{C}$ was instituted before the rate of excretion of derivatives had returned to their respective basal levels (Table II). The total recovery for the 4 infants shown in Figure 1 plus 4 others, not shown, in whom collections were sufficiently complete to make such calculations, ranged from 40 to 79 per cent when tyrosine was the amino acid ingested and from 43 to 74 per cent when phenylalanine was given.

The pattern of excretion of the various com-

TABLE II

Effect of ingestion of amino acids on urinary excretion of metabolites

\begin{tabular}{|c|c|c|c|c|c|c|c|c|c|c|c|c|c|c|c|}
\hline \multicolumn{16}{|c|}{ Tyrosine } \\
\hline \multirow{4}{*}{ Subject } & \multirow{4}{*}{ Age } & \multirow{4}{*}{$\underset{\text { acid }}{\text { Amino }}$} & \multicolumn{5}{|c|}{ Urinary output of derivatives of } & \multirow{4}{*}{ Subject } & \multirow{4}{*}{ Age } & \multirow{4}{*}{$\underset{\text { acid }}{\text { Amino }}$} & \multicolumn{5}{|c|}{ Urinary output of derivatives of } \\
\hline & & & \multirow{2}{*}{\multicolumn{2}{|c|}{ Phenylalanine* }} & \multicolumn{3}{|c|}{ Tyrosinet } & & & & \multirow{2}{*}{\multicolumn{2}{|c|}{ Phenylalanine* }} & \multicolumn{3}{|c|}{ Tyrosinet } \\
\hline & & & & & \multicolumn{2}{|c|}{$\begin{array}{c}\text { Ether-soluble } \\
\text { acids }\end{array}$} & \multirow{2}{*}{$\begin{array}{c}\text { Insol- } \\
\text { uble } \\
\text { tyro- } \\
\text { sine }\end{array}$} & & & & & & \multicolumn{2}{|c|}{$\underset{\text { acids }}{\text { Ether-soluble }}$} & \multirow{2}{*}{$\begin{array}{c}\text { Insol- } \\
\text { uble } \\
\text { tyro- } \\
\text { sine }\end{array}$} \\
\hline & & & P.P.A. & P.A. & Keto & Oxy & & & & & P.P.A. & P.A. & Keto & Oxy & \\
\hline \multirow{5}{*}{ R. S. } & days & $\underset{\text { per } k g m .}{\operatorname{grams}}$ & \multicolumn{5}{|c|}{ mgm. per 24 hours } & \multirow{4}{*}{ G. H. } & \multirow{2}{*}{$\begin{array}{c}\text { days } \\
9\end{array}$} & \multirow[t]{2}{*}{$\underset{\text { per } \mathrm{kgm} .}{\operatorname{grams}}$} & \multicolumn{5}{|c|}{ mgm. per 24 hours } \\
\hline & 12 & & 7 & 21 & 152 & 284 & 26 & & & & 0 & 24 & 3 & 20 & \multirow{2}{*}{$\begin{array}{r}13 \\
37 \\
220 \\
300 \\
336\end{array}$} \\
\hline & $\begin{array}{l}14 \\
15 \\
16 \\
17\end{array}$ & $\begin{array}{l}0.5 \\
0.5 \\
0.5 \\
0.5\end{array}$ & $\begin{array}{l}9 \\
8 \\
8 \\
7\end{array}$ & $\begin{array}{l}19 \\
22 \\
27 \\
28\end{array}$ & $\begin{array}{l}245 \\
319 \\
283 \\
267\end{array}$ & $\begin{array}{l}427 \\
659 \\
742 \\
748\end{array}$ & $\begin{array}{r}37 \\
74 \\
107 \\
109\end{array}$ & & \multirow{2}{*}{$\begin{array}{l}10 \\
11 \\
12 \\
13 \\
\\
14 \\
17\end{array}$} & \multirow[t]{2}{*}{$\begin{array}{l}1.0 \\
1.0 \\
1.0 \\
1.0\end{array}$} & $\begin{array}{l}1 \\
8 \\
7 \\
9\end{array}$ & $\begin{array}{l}21 \\
63 \\
57 \\
72\end{array}$ & $\begin{array}{r}50 \\
259 \\
251 \\
251\end{array}$ & $\begin{array}{r}80 \\
433 \\
663 \\
856\end{array}$ & \\
\hline & $\begin{array}{l}18 \\
22\end{array}$ & & $\begin{array}{l}7 \\
8\end{array}$ & $\begin{array}{l}27 \\
21\end{array}$ & $\begin{array}{l}239 \\
202\end{array}$ & $\begin{array}{l}727 \\
279\end{array}$ & $\begin{array}{l}85 \\
25\end{array}$ & & & & $\begin{array}{l}5 \\
0\end{array}$ & $\begin{array}{l}77 \\
32\end{array}$ & $\begin{array}{r}193 \\
4\end{array}$ & $\begin{array}{r}419 \\
16\end{array}$ & $\underset{15}{407 \|}$ \\
\hline & $\begin{array}{r}\ddagger 23 \\
\ddagger 24 \\
\ddagger 25 \\
\ddagger 26 \\
\ddagger 26 \\
27\end{array}$ & $\begin{array}{l}0.5 \\
0.5 \\
0.5 \\
0.5\end{array}$ & $\begin{array}{l}1 \\
1 \\
1 \\
0 \\
1\end{array}$ & $\begin{array}{l}21 \\
15 \\
17 \\
14 \\
\\
16\end{array}$ & \multicolumn{2}{|c|}{$\begin{array}{c}148 \S \\
36 \\
16 \\
16 \\
\\
20\end{array}$} & $\begin{array}{r}19 \\
16 \\
13 \\
9 \\
\\
10\end{array}$ & \multirow[t]{6}{*}{ J. C. } & \multirow{6}{*}{$\begin{array}{l}15 \\
16 \\
17 \\
18 \\
19 \\
20 \\
\\
21 \\
22 \\
23\end{array}$} & \multirow{6}{*}{$\begin{array}{l}1.0 \\
1.0 \\
1.0 \\
1.0 \\
2.0\end{array}$} & \multirow[t]{2}{*}{13} & \multirow[t]{2}{*}{$\begin{array}{l}63 \\
\\
69 \\
65\end{array}$} & 267 & 483 & 167 \\
\hline W. B. $\ddagger$ & 20 & & 3 & 25 & 5 & 3 & 10 & & & & & & & & \\
\hline & $\begin{array}{l}21 \\
22 \\
23 \\
24\end{array}$ & $\begin{array}{l}1.0 \\
1.0 \\
1.0 \\
1.0\end{array}$ & $\begin{array}{r}4 \\
16 \\
22 \\
20\end{array}$ & $\begin{array}{l}37 \\
27 \\
38 \\
38\end{array}$ & $\begin{array}{l}101 \\
394 \\
596 \\
598\end{array}$ & $\begin{array}{r}10 \\
40 \\
733 \\
1061\end{array}$ & $\begin{array}{r}40 \\
113 \\
264 \\
310\end{array}$ & & & & $\begin{array}{l}20 \\
20 \\
19\end{array}$ & $\begin{array}{l}49 \\
38 \\
37\end{array}$ & $\begin{array}{l}370 \\
285 \\
274\end{array}$ & $\begin{array}{l}791 \\
596 \\
490\end{array}$ & $\begin{array}{l}92 \\
57 \\
50\end{array}$ \\
\hline & $\begin{array}{l}25 \\
28\end{array}$ & & $\begin{array}{l}17 \\
15\end{array}$ & $\begin{array}{l}32 \\
28\end{array}$ & $\begin{array}{l}497 \\
413\end{array}$ & $\begin{array}{l}848 \\
510\end{array}$ & $\begin{array}{r}197 \\
95\end{array}$ & & & & & & & & \\
\hline & $\begin{array}{l}\ddagger \ddagger 29 \\
\ddagger \neq 30 \\
\ddagger \ddagger 31\end{array}$ & $\begin{array}{l}1.0 \\
1.0 \\
1.0\end{array}$ & $\begin{array}{l}18 \\
23 \\
24\end{array}$ & $\begin{array}{l}28 \\
30 \\
34\end{array}$ & & $\begin{array}{l}1988 \\
551 \\
599\end{array}$ & $\begin{array}{l}180 \\
240 \\
216\end{array}$ & & & & & & & & \\
\hline & $\begin{array}{l}\ddagger+32 \\
\ddagger 33\end{array}$ & & $\begin{array}{l}6 \\
2\end{array}$ & $\begin{array}{l}30 \\
23\end{array}$ & & $\begin{array}{r}363 \\
22\end{array}$ & $\begin{array}{l}44 \\
17\end{array}$ & & & & & & & & \\
\hline
\end{tabular}


TABLE II-Continued

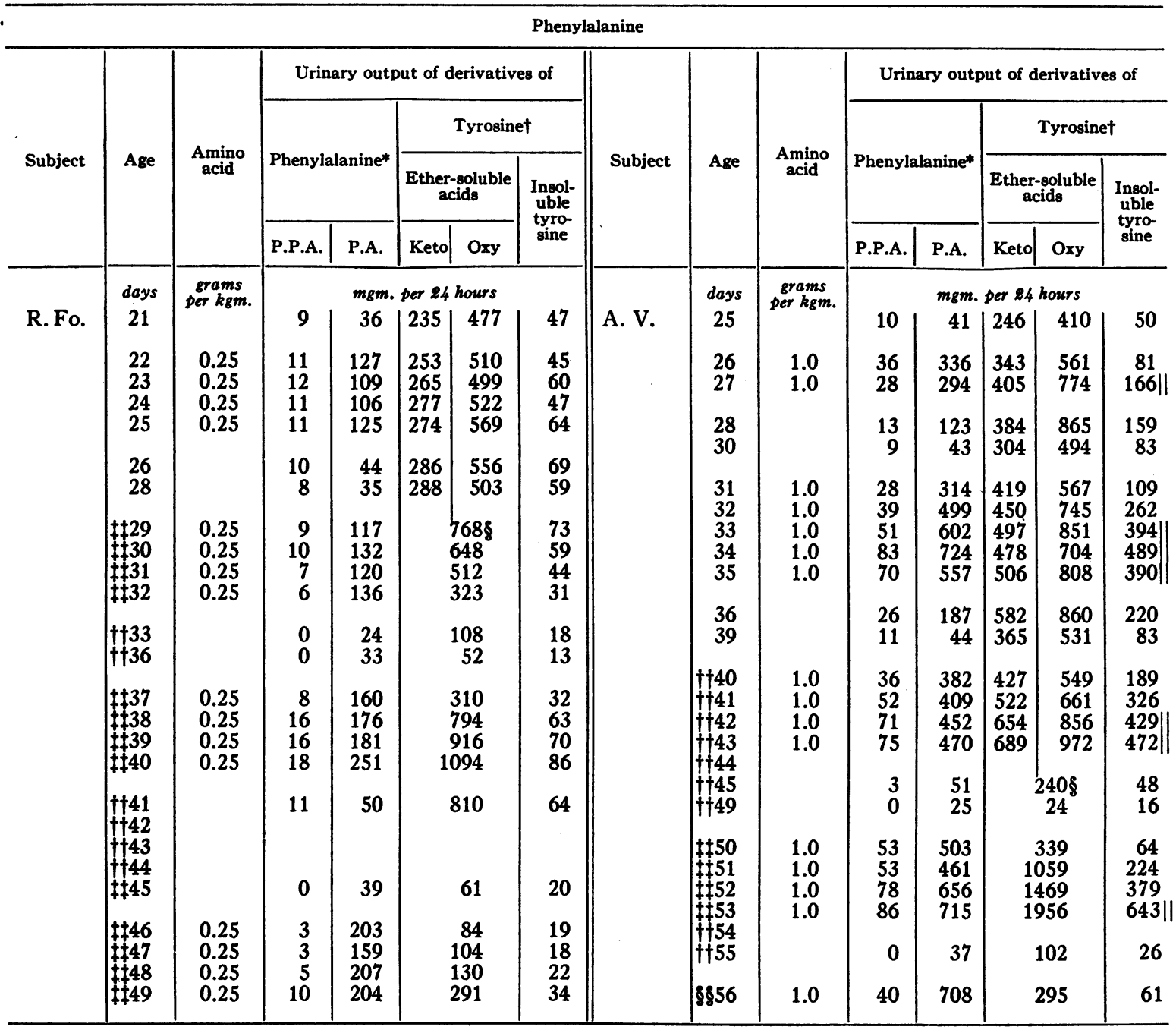

Cantinued on opposite page

ponents and the effect or absence of effect of ascorbic acid, illustrated in Figure 1, will be discussed below.

\section{Effect of tyrosine ingestion}

The data (Table II) confirm the previous findings $(1,2)$ of a prompt, marked, and persistent increase in urinary hydroxyphenyl compounds ( $p$ hydroxyphenylpyruvic acid, 1-p-hydroxyphenyllactic acid, and tyrosine) in the absence of dietary vitamin $C$. This response occurred with daily dosages of 0.5 to 2.0 grams per $\mathrm{kgm}$., for 4 to 5 days. For example, in R. S. (Table II and Figure 1) who received 0.5 gram of tyrosine per $\mathrm{kgm}$. per day, 78 per cent of the extra tyrosine absorbed from the gastrointestinal tract was recovered in the urine as tyrosine itself plus its keto and hydroxy derivatives.

The high rate of excretion of the ether-insoluble aromatic fraction, tyrosine, was striking in all 4 infants. It attained such a high level in G. H. (Table II) that his urine, as voided, contained gross crystals of tyrosine. ${ }^{2}$

Cessation of treatment was accompanied by a variable but steady decline in output of these metabolites. In 2 of the premature infants who

2 These crystals were purified and identified as 1-tyrosine by elementary analysis and optical rotation in $\mathrm{Dr}$. V. duVigneaud's laboratory, by his colleagues Dr. G. B. Brown and Dr. J. R. Rachele, to whom we are indebted. 
TABLE II-Continued

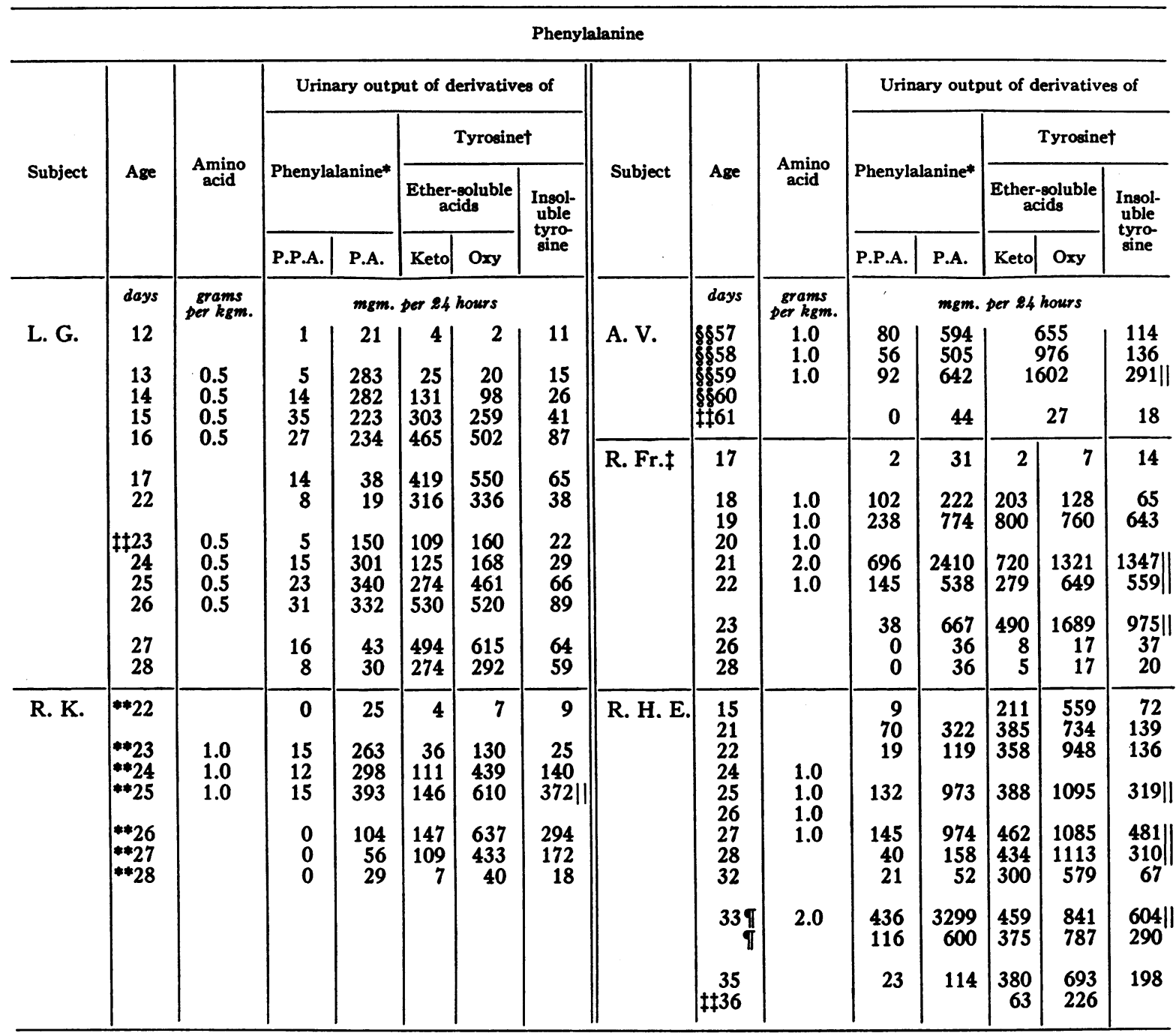

* P.P.A. represents phenylpyruvic acid; P.A., phenylalanine.

† Keto-acid represents p-hydroxyphenylpyruvic acid; oxy-acid, 1,p-hydroxyphenyllactic acid; both are expressed as tyrosine.

$\ddagger$ Full-term infant.

Combined ether-soluble compounds giving Millon reaction. Keto- and oxy-acids cannot be separated because of interfering action of excreted 1-ascorbic acid.

II Crystals of 1-tyrosine in urine.

II Twelve-hour periods.

** 0.025 gram of 1-ascorbic acid by mouth daily; he had received 0.8 gram during preceding 11 days.

t† 0.10 gram of 1 -ascorbic acid by mouth daily.

$¥ 0.20 \mathrm{gram}$ of 1 -ascorbic acid by mouth daily.

$\$ 80.40$ gram of 1-ascorbic acid by mouth daily.

received tyrosine, the excretion of the derivatives had returned to the control level within 3 days (G. H. and J. C.) and in the third, after 5 days (R. S.). In the full-term infant (W. B.), it had not reached the control level, which was very low, on the fourth day when subsequent supplements were given.
Attention is directed to the low and relatively constant levels of phenylalanine and its keto acid, phenylpyruvic acid, throughout the pre-, test, and post-periods of tyrosine ingestion. The slight apparent elevation in output of phenylalanine in one infant (G. H.) during tyrosine ingestion was undoubtedly due to the chemical error resulting from 


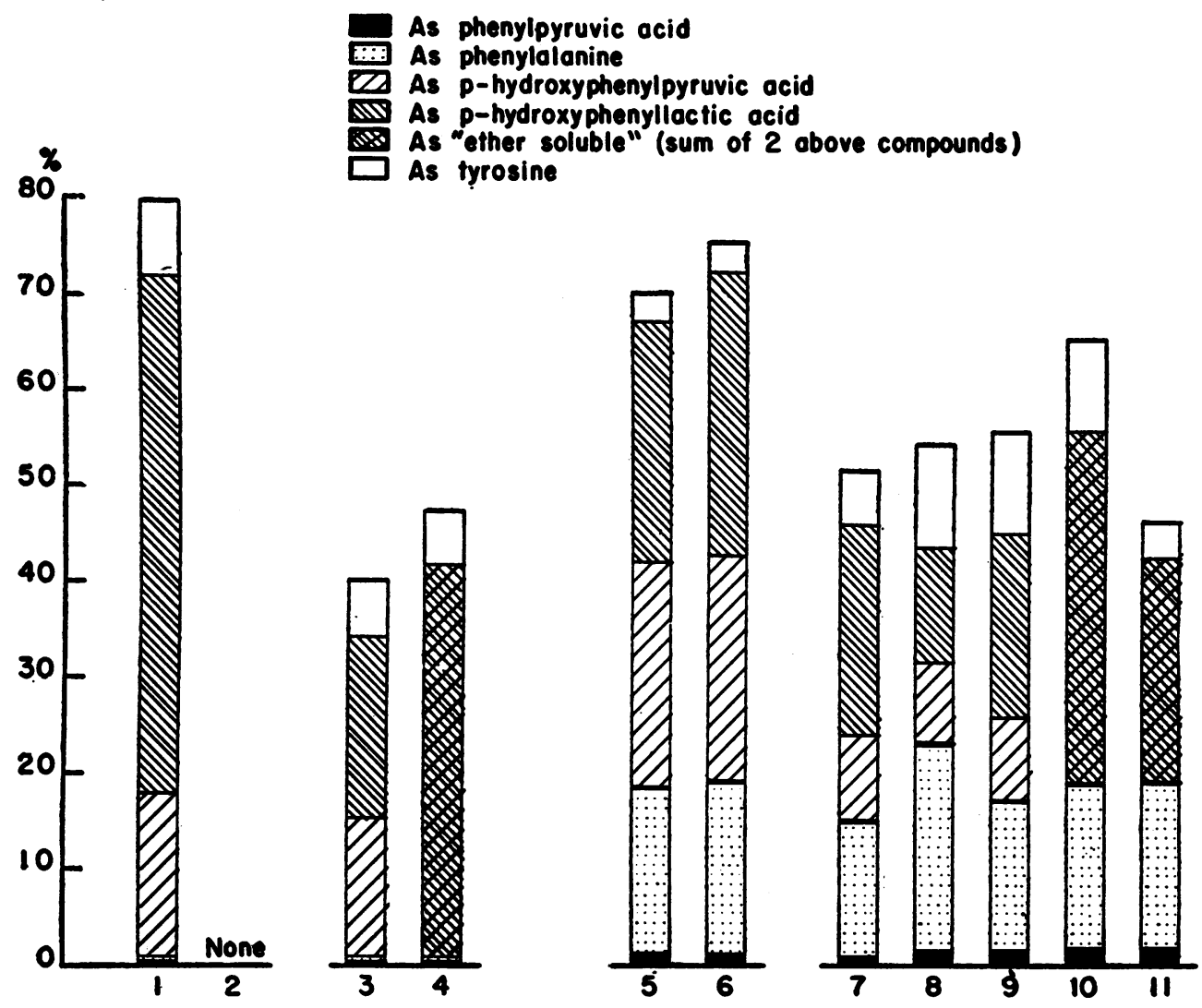

Fig. 1. Recovery in Urine of Extra Amino Acid Ingested

1. R. S. Premature. Tyrosine 0.5 gram per $\mathrm{kgm}$. daily for 4 days.

2. Same, with ascorbic acid 0.2 gram daily.

3. W. B. Full-term. Tyrosine 1.0 gram per $\mathrm{kgm}$. daily for 4 days.

4. Same infant; same dosage daily for 3 days; also received ascorbic acid 0.2 gram daily.

5. L. G. Premature. Phenylalanine $0.5 \mathrm{gram}$ per $\mathrm{kgm}$. daily for 5 days.

6. Same; also received a single dose of $0.2 \mathrm{gram}$ ascorbic acid.

7. A. V. Premature. Phenylalanine $1.0 \mathrm{gram}$ per $\mathrm{kgm}$. daily for 2 days.

8. Same infant; same dosage daily for 5 days.

9. Same infant; same dosage for 4 days; also ascorbic acid 0.1 gram daily.

10. Same, except that ascorbic acid dosage was 0.2 gram daily.

11. Same, except that ascorbic acid dosage was 0.4 gram daily.

interference by tyrosine. As previously noted, this error amounted to about $20 \mathrm{mgm}$. of apparent phenylalanine per $100 \mathrm{mgm}$. of tyrosine present. In the determinations (R. S. and W. B.) in which tyrosine was removed prior to analysis for phenylalanine, the latter values remained constant.

\section{Effect of phenylalanine ingestion}

The rise in urinary excretion of the ether-soluble phenolic compounds, p-hydroxyphenylpyruvic and 1-p-hydroxyphenyllactic acids (Table II), following the ingestion of $d, 1$-phenylalanine, was as high as or higher than it was after 1-tyrosine in equivalent dosage. Furthermore, the ether-insoluble component, 1-tyrosine, also reached high or higher levels, the amount excreted exceeding its solubility in urine so that all 4 infants (R. K., A. V., R. Fr., and R. H. E.) who received 1.0 gram of phenylalanine per kgm. of body weight per day, actually excreted crystals of 1-tyrosine, identified by chemical analysis. ${ }^{3}$

As might be expected, the increase in output of ether-soluble phenolic compounds and of tyrosine

8 See footnote 2. 
was much less striking in the infants R. Fo. and L. G. who received smaller doses of phenylalanine ( 0.25 gram and 0.5 gram per kgm. per day, respectively). However, even in the latter infant, the recovery of the ingested dose (Figure 1, column 5) was high, being 70 per cent, of which 52 per cent was in the form of tyrosine derivatives.

The disappearance of metabolites 4 days after cessation of phenylalanine ingestion occurred spontaneously in the full-term infant R. Fr. In the premature infants R. Fo., L. G., A. V., and R. H. $E$., they were decreasing but were still above the initial levels when a subsequent dose was given, 3 to 6 days after the last preceding one.

The excretion of phenylalanine itself was markedly increased after ingestion of this amino acid, the extent of the overflow being parallel to the size of the dose. An increased output of phenylpyruvic acid began to appear only with the higher phenylalanine dosage, was not great except when phenylalanine overflow was notably high (R. Fr. on the 21 st day and R. H. E. on the 33rd day, when each received 2.0 grams of phenylalanine per $\mathrm{kgm}$. ), and subsided promptly on cessation of amino acid administration.

Infant A. V. (Figure 1, columns 7 and 8) illustrates well the large proportion of phenylalanine recovered as such and the large amount converted into tyrosine, with a relatively lower but still conspicuous increase in ether-soluble derivatives. In the first test period, in which only 2 doses of phenylalanine of 1.0 gram per $\mathrm{kgm}$. each were given, of a total recovery of 52 per cent, 14 was in the form of phenylalanine and slightly less than 6 per cent as tyrosine; in the second series, in which 5 such doses were given, 54.5 per cent was recovered, of which 21 per cent appeared as phenylalanine and 11 per cent as tyrosine.

\section{Fecal excretion of tyrosine and phenylalanine}

The higher urinary output of intermediary metabolites after phenylalanine than after tyrosine ingestion might be due theoretically to its greater metabolizability or to its better absorption from the gastrointestinal tract. That the latter plays a rôle was suspected when curdy stools from infant G. H. were found to contain significant amounts of tyrosine. Consequently, quantitative fecal analyses were carried out in 2 subjects, one receiving phenylalanine and the other tyrosine in equivalent dosage (Table III).

The ingestion by infant L. G. of 0.5 gram of phenylalanine per kgm. per day for 4 days without concurrent vitamin $C$ administration was not accompanied by any significant change in fecal

TABLE III

Fecal excretion of tyrosine and phenylalanine after ingestion of these amino acids

\begin{tabular}{|c|c|c|c|c|c|c|c|c|c|c|}
\hline \multirow{2}{*}{$\underset{\text { Age }}{\text { R. S. }}$} & \multicolumn{2}{|c|}{ Intake } & \multicolumn{3}{|c|}{ Fecest } & \multirow{2}{*}{$\underset{\text { Age }}{\text { L. G. }}$} & \multicolumn{2}{|c|}{ Intake } & \multicolumn{2}{|c|}{ Fecest } \\
\hline & Tyrosine & $\begin{array}{c}\text { Ascorbic } \\
\text { acid }\end{array}$ & Tyrosine & $\begin{array}{l}\text { Phenyl- } \\
\text { alanine }\end{array}$ & $\begin{array}{l}\text { Ingested } \\
\text { tyrosine lost } \\
\text { in feces }\end{array}$ & & $\begin{array}{l}\text { Phenyl- } \\
\text { alanine }\end{array}$ & $\begin{array}{c}\text { Ascorbic } \\
\text { acid }\end{array}$ & Tyrosine & $\begin{array}{l}\text { Phenyl- } \\
\text { alanine }\end{array}$ \\
\hline days & \multicolumn{2}{|c|}{ grams } & \multicolumn{2}{|c|}{ mgm. per 24 hours } & per cent & days & \multicolumn{2}{|c|}{ grams } & \multicolumn{2}{|c|}{ mgm. per 24 hours } \\
\hline $\begin{array}{l}10 \\
11 \\
12 \\
13 \\
14 \\
15 \\
16 \\
17 \\
18\end{array}$ & $\begin{array}{l}1.045^{*} \\
1.050 \\
1.080 \\
1.100\end{array}$ & & $\begin{array}{r}12 \\
12 \\
12 \\
\\
192 \\
203 \\
214 \\
208 \\
29\end{array}$ & $\begin{array}{l}15 \\
15 \\
15 \\
\\
17 \\
17 \\
24 \\
24 \\
12\end{array}$ & 18 & $\begin{array}{l}11 \\
12 \\
13 \\
14 \\
15 \\
16 \\
17\end{array}$ & $\begin{array}{l}1.39^{*} \\
1.40 \\
1.40 \\
1.45\end{array}$ & & $\begin{array}{l}17 \\
17 \\
21 \\
21 \\
38 \\
38 \\
38\end{array}$ & $\begin{array}{l}23 \\
23 \\
16 \\
16 \\
26 \\
26 \\
26\end{array}$ \\
\hline $\begin{array}{l}21 \\
22 \\
23 \\
24 \\
25 \\
26 \\
27\end{array}$ & $\begin{array}{l}1.18^{*} \\
1.20 \\
1.21 \\
1.25\end{array}$ & $\begin{array}{l}0.2 \\
0.2 \\
0.2 \\
0.2 \\
0.025\end{array}$ & $\begin{array}{r}25 \\
25 \\
126 \\
364 \\
477 \\
345 \\
63\end{array}$ & $\begin{array}{r}8 \\
8 \\
9 \\
35 \\
21 \\
21 \\
52\end{array}$ & 22 & $\begin{array}{l}21 \\
22 \\
23 \\
24 \\
25 \\
26 \\
27 \\
28\end{array}$ & $\begin{array}{l}1.57^{*} \\
1.61 \\
1.62 \\
1.68\end{array}$ & 0.2 & $\begin{array}{l}27 \\
27 \\
20 \\
20 \\
19 \\
19 \\
42 \\
42\end{array}$ & $\begin{array}{l}37 \\
37 \\
34 \\
34 \\
29 \\
29 \\
66 \\
66\end{array}$ \\
\hline
\end{tabular}

* 0.5 gram per kgm. body weight per day.

$\dagger$ Analyses made during fore and after periods on pooled samples of from 1 to 3 days, and daily during the test periods. 
output of either amino acid. In contrast, similar dosage of tyrosine in another infant (R. S.) resulted in a notable increase in fecal loss of this amino acid. Cessation of tyrosine ingestion was accompanied by a prompt return to the control levels of fecal loss. However, even when there was the greatest loss (R. S., 24th, 25th, and 26th days), at least two-thirds of the ingested amino acid was absorbed.

\section{Absence of homogentisic acid in urine}

At no time was homogentisic acid detected in the urine of either full-term or premature infants, either by darkening of the urine on standing or in a number of specimens on alkalinization and aeration.

\section{Effect of vitamin $C$}

Prevention of excretion of intermediary metabolites in a 4-day period of concurrent daily administration of ascorbic acid and amino acid was accomplished in one premature infant, R. S. (Table II ; Figure 1, column 2), whose daily dosages of supplements were tyrosine, 1.21 grams ( 0.5 gram per $\mathrm{kgm}$.) and ascorbic acid, 0.2 gram. In this infant, the first dose of ascorbic acid preceded the amino acid ingestion by 5 hours.

In one full-term infant given tyrosine (W. B.) and 2 premature infants given phenylalanine ( $R$. Fo. and A. V.), ascorbic acid, administered in liberal amounts 2 to 8 hours before the start of the series of test observations with amino acid and continued daily throughout the period, failed to prevent or to diminish appreciably the output of derivatives in the urine. In one infant (L. G.), a single dose of 1 -ascorbic acid ( 0.2 gram), given on the first day of a series of test observations with phenylalanine ( 0.5 gram per $\mathrm{kgm}$. per day for 4 days), was without significant effect on the excretion of aromatic derivatives (Table II).

In R. K., ascorbic acid was given for a number of days prior to amino acid ingestion with the purpose of saturating the infant's tissues. Although the absence of aromatic compounds in the urine during the control period presumably reflects the accomplishment of this object, the vitamin did not prevent the excretion of large amounts of all the derivatives, including tyrosine crystals, when phenylalanine was administered (Table II).

Contrary to expectation, no relationship ap- peared to exist between the dosage of ascorbic acid and its effect. The pattern of excretion is closely similar in $R$. K., receiving $25 \mathrm{mgm}$. of the vitamin daily, to that in $\mathrm{A}$. V., receiving increasing amounts up to $400 \mathrm{mgm}$. daily. In Figure 1, columns 9,10 , and 11 show strikingly the complete lack of effect of even these high dosages on the urinary recovery of ingested phenylalanine and its derivatives. The $200 \mathrm{mgm}$. of vitamin given daily to R. Fo. in the series from the 29 th to the 32nd day was divided into 2 equal doses, whereas from the 37th to the 40th and from the 45th to the 49th days the same total daily amount was subdivided into 6 doses. Although saturation with respect to vitamin $C$ might be expected to be better maintained with the frequent dosage, it did not prevent the defect in metabolism of ingested phenylalanine.

Fecal excretion of ingested tyrosine and phenylaline (Table III) was not significantly affected by concurrent administration of vitamin $\mathrm{C}$.

The one consistently positive effect of ascorbic acid as shown in the preceding papers $(1,2)$ was the rapid disappearance of derivatives after amino acid ingestion was stopped. This result was obtained in all of the infants who received supplements of vitamin $C$ in the post-periods. This effect is strikingly illustrated in infant W. B. (Table II) by contrasting the figures for the 33rd day with ascorbic acid ingestion and those of the 25th and 28th days without vitamin supplements; in $R$. Fo., on the 33rd and 36th days in contrast to the 26th and 28th; and in A. V., on the 45th and 49th days in contrast to the 36th and 39th. This prompt drop in the case of $A$. V. recurred at the end of 2 other test periods of combined amino acid and vitamin ingestion (55th and 61st days). In R. K. also, there was a disappearance of the derivatives within 3 days after the cessation of ingestion of amino acid.

\section{DISCUSSION}

These observations suggest that in healthy human beings (premature and full-term infants) as in the animal studies cited (3 to 9), 1-tyrosine can be formed from d,1-phenylalanine. This conversion proceeded to such a degree that one or 2 days after the first of a series of daily oral doses of phenylalanine of 1.0 gram per $\mathrm{kgm}$. of body weight, the urinary excretion of tyrosine in these 
subjects exceeded its solubility and gross crystals of this substance were voided in the urine.

The reverse conversion did not occur. When tyrosine was ingested, this compound itself, as well as its keto and oxy derivatives, was excreted in large amounts, but the urinary output of phenylalanine and its keto acid, phenylpyruvic, remained minimal. This finding is consistent with the observations of Womack and Rose (5) that tyrosine in the diet of rats cannot replace the essential phenylalanine.

Assay of the feces revealed that absorption of ingested phenylalanine was practically complete. Tyrosine, on the other hand, was not completely absorbed, 18 to 22 per cent of ingested tyrosine being recovered in the feces of one subject.

Premature infants receiving a diet containing 5 to 7 grams of protein per $\mathrm{kgm}$. (providing a total of about 0.5 gram of tyrosine plus phenylalanine per kgm.), as in previous studies $(1,2)$, excreted in the urine large amounts of p-hydroxyphenylpyruvic acid and p-hydroxyphenyllactic acid. Even with high initial levels, further repeated administration of tyrosine or phenylalanine in pure form led to the recovery of 40 to 70 per cent of the ingested amino acid and its derivatives. Similar recoveries were obtained in 2 full-term infants who were receiving the same high protein diet but whose control levels of aromatic compounds in the urine were extremely low.

The effect of ascorbic acid, previously shown $(1,2 . b)$ to prevent the rise of metabolites when a single dose of either amino acid was given, was not manifest in these observations with repeated dosage except in one infant in whom $200 \mathrm{mgm}$. of ascorbic acid daily prevented the appearance of derivatives of 0.5 gram of tyrosine per $\mathrm{kgm}$. per day (W. B.). The principal difference in the present study from the earlier ones was the repeated and relatively high dosage of amino acids. Presumably this high dosage overwhelmed the vitamin's opposing action, the nature of which is still in the realm of study rather than of established fact (20). Even with such large dosage, it is noteworthy than when amino acid administration was stopped, ascorbic acid was then able to exert its usual effect, shown by the rapid drop in excretion of the derivatives in contrast to their persistence when no ascorbic acid was given.

The absence of homogentisic acid in the urine of these subjects, in contrast to the results of Sealock and his colleagues $(7,20)$ with guinea pigs, appears to be due to a specific difference rather than, as suggested by Sealock (20) in referring to the earlier papers $(1,2)$, to small dosage of the amino acids.

As in the previous work (2.a), it was again found that more p-hydroxyphenyllactic acid was excreted than p-hydroxyphenylpyruvic acid, in contrast to the results reported in animals (7.b) in which the 2 ether-soluble tyrosine derivatives were present in reverse proportions.

Another point worthy of brief mention is the extremely small amount of phenylpyruvic acid excreted, except in 2 instances when 2.0 grams per $\mathrm{kgm}$. of phenylalanine was administered. Even then the highest amounts excreted were less than 0.7 gram per day, in contrast to several grams usually eliminated by subjects with phenylpyruvic oligophrenia (14).

\section{SUM MARY}

Ten healthy male infants, 8 premature and 2 full-term, were observed while on constant highprotein, vitamin C-free diets. These diets were calculated to contain about 0.5 gram of tyrosine plus phenylalanine per $\mathrm{kgm}$. of body weight. Various dosages of extra 1-tyrosine and d,1phenylalanine were administered in pure form and the urine quantitatively collected and analyzed for these aromatic amino acids and their derivatives. In some of the test periods, ascorbic acid was also given.

In both premature and full-term infants, the repeated ingestion of d,1-phenylalanine resulted in the appearance in the urine not only of this amino acid but also of 1-tyrosine and its derivatives, $\mathrm{p}$ hydroxyphenylpyruvic acid and p-hydroxyphenyllactic acid, in large amounts. When the daily dosage of phenylalanine was 1.0 gram per kgm., the excretion of tyrosine exceeded its solubility in the urine so that gross crystals of this amino acid were voided. The sum of the aromatic amino acids and their derivatives recovered in the urine, above the amounts present in control periods, represented 44 to 73 per cent of the extra phenylalanine ingested.

This reaction is apparently irreversible, as shown by the absence of significant excretion of phenylalanine and phenylpyruvic acid after equivalent 1tyrosine ingestion, though tyrosine and its keto 
and hydroxy derivatives appeared in abundant amounts, accounting for 40 to 80 per cent of the ingested or absorbed amino acid.

These results suggest that in the human organism, as in lower animals, 1-tyrosine in the diet cannot replace, d,1-phenylalanine which, in animals, has been shown to be essential.

Analyses of the feces of 2 subjects showed that no appreciable amount of phenylalanine is lost by this route, whereas 18 to 22 per cent of ingested tyrosine may be excreted in the feces.

Even with large repeated dosage of the amino acids, the babies, unlike guinea pigs and rats, did not excrete homogentisic acid.

Vitamin C (1-ascorbic acid), previously shown to diminish or abolish the excretion of aromatic metabolites after single dosage of either amino acid, was, except in one infant, ineffective when jointly given with repeated and large dosage of either tyrosine or phenylalanine. The usual vitamin effect reappeared promptly on cessation of amino acid ingestion, as evidenced by rapid disappearance of the derivatives from the urine.

\section{BIBLIOGRAPHY}

1. Levine, S. Z., Marples, E., and Gordon, H. H., A defect in the metabolism of aromatic amino acids in premature infants: The role of vitamin C. Science, 1939, 90, 620.

2. a. Levine, S. Z., Marples, E., and Gordon, H. H., A defect in the metabolism of tyrosine and phenylalanine in premature infants. I. Identification and assay of intermediary products. J. Clin. Invest., 1941, 20, 199.

b. Levine, S. Z., Gordon, H. H., and Marples, E., A defect in the metabolism of tyrosine and phenylalanine in premature infants. II. Spontaneous occurrence and eradication by vitamin C. J. Clin. Invest., 1941, 20, 209.

3. Embden, G., and Baldes, K., Ueber den Abbau des Phenylalanins im tierischen Organismus. Biochem. Ztschr., 1913, 55, 301.

4. Embden, G., and Schmitz, G., Ueber synthetische Bildung von Aminosäuren in der Leber. Biochem. Ztschr., 1910, 29, 423.

5. Womack, M., and Rose, W. C., Feeding experiments with mixtures of highly purified amino acids. VI. The relation of phenylalanine and tyrosine to growth. J. Biol. Chem., 1934, 107, 449.

6. Papageorge, E., and Lewis, H. B., Comparative studies of the metabolism of the amino acids. VII. Experimental alcaptonuria in the white rat. J. Biol. Chem., 1938, 123, 211.

7. a. Sealock, R. R., and Silberstein, H. E., Control of experimental alcaptonuria by means of vitamin $\mathrm{C}$. Science, 1939, 90, 517. b. Sealock, R. R., and Silberstein, H. E., The excretion of homogentisic acid and other tyrosine metabolites by the vitamin C-deficient guinea pig. J. Biol. Chem., 1940, 135, 251.

8. Kotake, Y., Masai, Y., and Mori, Y., Ueber das Verhalten des Phenylalanins im tierischen Organismus. Ztschr. f. physiol. Chem., 1922, 122, 195.

9. Moss, A. R., and Schoenheimer, R., The conversion of phenylalanine to tyrosine in normal rats. J. Biol. Chem., 1940, 135, 415.

10. Moss, A. R., The conversion of $\beta$-phenyllactic acid to tyrosine in normal rats. J. Biol. Chem., 1941, 137, 739.

11. a. Neubauer, O., and Falta, W., Ueber das Schicksal einiger aromatischer Säuren bei der Alkaptonurie. Ztschr. f. physiol. Chem., 1904, 42, 81.

b. Neubauer, O., Ueber den Abbau der Aminosäuren im gesunden und kranken Organismus. Deutsches Arch. f. klin. Med., 1909, 95, 211.

12. Sealock, R. R., Galdston, M., and Steele, J. M., Administration of ascorbic acid to an alkaptonuric patient. Proc. Soc. Exper. Biol. and Med., 1940, 44, 580.

13. Medes, G., A new error of tyrosine metabolism: tyrosinosis. The intermediary metabolism of tyrosine and phenylalanine. Biochem, J., 1932, 26, 917.

14. a. Jervis, G. A., Metabolic investigations on a case of phenylpyruvic oligophrenia. J. Biol. Chem., 1938, 126, 305.

b. Dann, M., Marples, E., and Levine, S. Z., Phenylpyruvic oligophrenia. Report of a case in an infant with quantitative chemical studies of the urine. J. Clin. Invest., 1943, 22, 87.

15. Bessey, O. A., A method for the determination of small quantities of ascorbic acid and dehydroascorbic acid in turbid and colored solutions in the presence of other reducing substances. J. Biol. Chem., 1938, 126, 771.

16. a. Hoag, L. A., Apparatus for quantitative collection of urine and of stools in male infants. Am. J. Dis. Child., 1932, 44, 770.

b. Gordon, H. H., Levine, S. Z., Wheatley, M. A., and Marples, E., Respiratory metabolism in infancy and in childhood. XX. The nitrogen metabolism in premature infants: Comparative studies of human milk and cow's milk. Am. J. Dis. Child., 1937, 54, 1030.

17. Folin, O., and Ciocalteu,-V., On tyrosine and tryptophane determinations in proteins. J. Biol. Chem., 1927, 73, 627.

18. Kapeller-Adler, R., Ueber eine neue Reaktion zur qualitativen und quantitativen Bestimmung des Phenylalanins. Biochem. Ztschr., 1932, 252, 185.

19. Jervis, G. A., Block, R. J., Bolling, D., and Kanze, E., Chemical and metabolic studies on phenylalanine. II. The phenylalanine content of the blood and spinal fluid in phenylpyruvic oligophrenia. J. Biol. Chem., 1940, 134, 105.

20. Sealock, R. R., The relation of vitamin $C$ to the metabolism of the aromatic amino acids. Federation Proceedings, 1942, 1, 287. 